\title{
Pistacia Resin as a Potential Preventative Therapy for Alzheimer's Disease
}

\author{
Mohammad Sharif Sharifi*, Renata Andrzejewska and Neda Blackwood \\ Food and Pharmaceutical Industries, Australia
}

Submission: April 13, 2018; Published: May 21, 2018

*Corresponding author: Mohammad Sharif Sharifi, Australian Food and Pharmaceutical Industries, 5 McIntyre Way Bomaderry, NSW, Australia Tel: +61 2 44224605; Email: m.sharifi@foodpharmaindu.com

\section{Mini Review}

Alzheimer's disease (AD) is a progressive neurodegenerative disease. Today, Alzheimer's disease is known to almost everyone. The rise of life expectancy has increased the Alzheimer's risk factor and all efforts for finding a cure have been exhausted. AD is the most common neurological degenerative disease in people over 65 years of age. It is a form of dementia with a gradual onset, usually beginning with symptoms of impaired short-term memory and impaired cognitive function, accompanied by mood changes. Dementia may occasionally be difficult to distinguish from normal ageing [1], however, it is a pathological process.

Helicobacter pylorus (H. pylori) is one of the most significant discoveries in gastroenterology in the past century. It is associated with a wide range of gastroduodenal pathology, gastric cancer and non-gastric diseases; AD, Parkinson's disease, atherosclerosis, and cardiovascular ischemia [2-4]. H. pylori are not the only risk factor for AD. Infectious agents in general have been proposed as potential causes of AD [5]. This makes Mastic gum and other tested gum by the author [6], including Araucaria heterophylla (Sharifi unpublished data), a good candidate for preventing AD. The said gum has demonstrated anti-microbial activities against various Gram-positive and Gram-negative human pathogen [7]. A high prevalence of $H$. pylori infection has been documented in patients with AD [6]. The effect of $H$. Pylori eradication on the AD cognitive (MMSE: Mini Mental State Examination and CAMCOG: Cambridge Cognitive Examination for the Elderly) and functional (FRSSD: Functional Rating Scale for Symptoms of Dementia) status parameters in patients were assessed. A total of 50 patients with $\mathrm{AD}$ and 30 agematched anaemic controls underwent an upper gastrointestinal endoscopy. Gastric mucosal biopsies were also obtained to detect the presence of $H$. Pylori infection by histologic analysis and rapid urease test. The serum anti-H. Pylori-specific IgG level was also analysed by enzyme-linked immunosorbent assay. The $H$. pylori positive patients with AD were treated with triple eradication regimen. All patients were followed up for 2 years while receiving cholinesterase inhibitors. Cognitive and functional status parameters improved in the subgroup of patients where H.pylori eradication was successful $(\mathrm{P}<0.001$ and $\mathrm{P}=0.049$ for MMSE and CAMCOG, respectively; $\mathrm{P}<0.001$ for FRSSD). Cognitive and functional status parameters remained unchanged in patients where the eradication did not succeed.

$H$. pylori eradication may positively influence AD manifestations, suggesting a link between $\mathrm{AD}$ and $H$. pylori infection. Antibiotic resistance in $H$. pylori has emerged as a significant clinical problem. Furthermore, contemporary therapy is expensive and complex, this presents problems particularly for people with low socioeconomic status. In this review we suggest an alternative therapy based on observations of traditional medicine for gastric diseases in the Mediterranean. This traditional therapy centres on the trunk exudates of Pistacia genus trees.

Extensive studies have been carried out to determine antimicrobial activities of trunk exudates from the genus Pistacia, in particular Pistacia lentiscus (Mastic Gum). Mastic gum is a viscous light-green liquid obtained from the bark of Pistacia lentiscus which belongs to the Anacardiaceae family. The gum has been fractionated to investigate the antimicrobial activity of the whole gum and its fractions against various strains of H. pylori.

The chemical entities of Mastic, Kurdica, Mutica and Cabolica gums from the genus Pistacia have been isolated and characterised by GC-Mass Spectrometry, High Performance Liquid Chromatography and Column Chromatography [8]. These chemical entities were screened for anti-microbial activities against nine strains of $H$. pylori and some other Gram-negative and Gram-positive bacteria. The most bioactive components were structurally analysed. These components mimic steroid compounds, in particular, the known antibiotic Fusidic acid [9]. Some of these chemical entities have produced promising 
data that could lead to the development of a novel class of antimicrobial agents that may have application in the treatment of infectious disease.

Kill kinetics have been also performed, and the produced data were evaluated by Generalized Multiplicative Analysis of Variance (GEMANOVA) for the bactericidal and bacteriostatic activities which can be clinically significant. The isolated components were all bactericidal [10].

\section{References}

1. Kumar V, Abbas AK, Fausto N, Michell RN (2007) Robbins Basic Pathology ( $8^{\text {th }}$ edn $)$. Philadelphia, USA.

2. Tan HJ, Goh KL (2012) Extra gastrointestinal manifestations of Helicobacter pylori infection: facts or myth? A critical review. J Dig Dis 13(7): 342-349.

3. Tsang KW, Lam SK (1999) Helicobacter pylori and extra-digestive diseases. J Gastroenterol Hepatol 14(9): 844-850.

4. Wedi B, Kapp A (2002) Helicobacter pylori infection in skin diseases: a critical appraisal. Am J Clin Dermatol 3(4): 273-282.

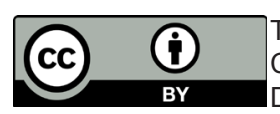

This work is licensed under Creative Commons Attribution 4.0 Licens DOI: 10.19080/OAJNN.2018.07.555720
5. Kountouras J, Tsolaki M, Gavalas E, Boziki M, Zavos C, et al. (2006) Relationship between Helicobacter pylori infection and Alzheimer disease. Neurology 66(6): 938-940.

6. Kountouras J, Boziki M, Gavalas E, Zavos C, Grigoriadis N, et al. (2009) Eradication of Helicobacter pylori may be beneficial in the management of Alzheimer's disease. J Neurol 256(5): 758-767.

7. Sharifi MS (2006) Fractionations and analysis of trunk exudates from Pistacia genus in relation to antimicrobial activity. College of Health and Science University of Western Sydney, Sydney, Australia, p. 284.

8. Sharifi MS, Hazell SL (2008) Characterization of genus Pistacia in relation to antimicrobial activity. Traditional \& Complementary Medicine pp. 1008-1013.

9. Sharifi MS, Hazell SL (2012) Structural Relationship Activities of Triterpenoids. Journal of Infectious Disease 31.

10. Ebrahimi D, Sharifi MS, Hazell SL, Hibbert DB (2008) Generalized multiplicative analysis of variance of kill kinetics data of antibacterial agents. Chemometrics and Intelligent Laboratory Systems 92(2): 101109.

\section{Your next submission with Juniper Publishers will reach you the below assets}

- Quality Editorial service

- Swift Peer Review

- Reprints availability

- E-prints Service

- Manuscript Podcast for convenient understanding

- Global attainment for your research

- Manuscript accessibility in different formats

( Pdf, E-pub, Full Text, Audio)

- Unceasing customer service

Track the below URL for one-step submission https://juniperpublishers.com/online-submission.php 